\title{
The Neapolitan School of Fencing: \\ Its Origins and Early Characteristics
}

Charles Blair

\begin{abstract}
The Neapolitan school of fencing, which received official sanction after the reunification of Italy in the nineteenth century, originated in the seventeenth century. It was originally best known as a system of sword and dagger fencing. It is documented as such in both Italian and Spanish sources during the reign of Carlos II and the War of the Spanish Succession (1665-1714). This article discusses the evidence from both sets of sources during this period, comparing and contrasting the Neapolitan approach to previous, contemporary and subsequent approaches in order to provide the necessary historical context for its origin and development.
\end{abstract}

\section{ORIGIN OF THE NEAPOLITAN SCHOOL}

The Neapolitan school of fencing begins with Giovan Battista ("Titta") Marcelli, who died in $1685.1^{1}$ He lived until he was past 90 , so he cannot have been born later than 1595.

Marcelli was from an old Roman family, but at some point he moved from Rome to Naples; we do not know when or why. We do know that he left a brother Lelio behind in Rome, and a son who published a treatise in 1686. Marcelli not only lived to an advanced age; we are told that even towards the end of his life he continued to give lessons and move like a man in the prime of life.

Marcelli was known for a lightning-fast lunge: before one realized what was happening, one was hit; therefore, one could not craft a defence. Marcelli was not only a good fencer; he was able to reproduce results in his students, some of whom became masters in their own right. One of them had a reputation for calling out a target on a noncompliant opponent's body, then proceeding to hit it.

Giovan Battista Marcelli had a student, Giovanni Mattei, who taught his younger brother, Francesco Antonio Mattei, and Giuseppe Villardita, who held his fellow student in high esteem. (Villardita 1670 21) Both the younger Mattei (1669) and Villardita $(1670,1673)$ would go on to write treatises describing Marcelli's system of fencing. The younger Mattei taught Nicola Terracusa e Ventura, who stamped out the school of Pallavicini in Sicily. ${ }^{2}$

1 Details of Marcelli's life are taken from D'Alessandro (1723).

2 See Gelli (1890 96-97; 183), citing Florio, Blasco, Progresso della scienza della scherma delle Due Sicilie (Catania: 1865), 16-17. 
Like Villardita, Pallavicini was Sicilian; he, too, published treatises in 1670 and 1673 . He never refers to Mattei or Villardita by name. He simply calls them li moderni, the moderns, and refers to Mattei as "the modern author" or "our modern author". Though Pallavicini has clearly read Mattei's 1669 treatise, since he cites it, it does not appear in his bibliography (1670). He is highly critical of this school.

Pallavicini has great regard for Giovan Battista Marcelli, while at the same time clearly detesting what he considers to be the latter's upstart followers, whose style of fencing he refers to as Neapolitan. He says that they claim to have invented things which are to be found in older treatises. Pallavicini is self-consciously an old-school teacher. By contrast, Marcelli's son regarded the fencing of the past as almost unrecognizable when compared to the fencing of his day, "and not without reason, because since it consists completely in practice, to the extent that it has been practiced from its beginning to the present times, to that extent it has been more perfected, and today it is found brought to inalterable perfection". (1686 II I I 3)

Now, it is true, when reading their treatises, that the Neapolitans did claim that the elder Marcelli invented some things, such as the stance (la pianta) and the straight thrust (la stoccata dritta). If pushed they would say that Marcelli did not invent them, but that he did perfect them. (Cf. Marcelli 1686 II I I 2-3 on the stance.) The treatises of Pallavicini and the younger Marcelli (half a generation later) are peppered with evidence of the ongoing debate between the old and the new schools. ${ }^{3}$

\section{THE ITALIAN EVIDENCE}

We now turn to a brief introduction to what the elder Marcelli taught, drawn from the treatises of Mattei, Villardita, and the younger Marcelli, as well as on a work by Giuseppe D'Alessandro, not a fencing master, but a Neapolitan duke; it echoes much of what the masters taught, and provides much interesting detail.

\section{The Stance}

We begin with the pianta. For most purposes the translation of "stance" will do, though other translations are possible in some contexts, such as "position" or "positioning". The Spanish in period will use the cognate, planta, to describe their own stance as opposed to the Italian pianta.

The following description of the pianta as taught by the elder Marcelli is from Mattei (1669 14-16). The description in Villardita (1670 23-24) is virtually identical. Substantially similar is that of the younger Marcelli (1686 I I 1-2).

\footnotetext{
3 One also has to note that Villardita, who publishes in the same years that Pallavicini does, entitles his treatises La scherma Siciliana (1670) and Trattato della scherma Siciliana (1673). However, he is clearly describing the Neapolitan school. Both Pallavicini and Villardita were Sicilian, and Pallavicini makes comments which plainly indicate that he is proud of that fact. One has to wonder, therefore, if Villardita's titles were not deliberately chosen, as if to say, this (nevertheless) is Sicilian fencing (as it should be practiced).
} 
The gentleman who wishes to profit bimself by this science should first take the weapons in hand and then advance the right foot not more than the length of a pace from the left foot according to the proportiont of the man. I say a proportionate pace, neither long nor short, since if it is very wide, it will be disunited of force, and very narrow would be improper, and that maxim would be realized, "All excess is an enemy of nature", taking good care that the right foot is in a straight line with the heel of the left foot. Bend the left knee as much as suffices to bend the leg and thigh, and that the aforesaid bent knee is directly over the point of the corresponding foot, the positioning of which, remaining completely firm on the ground, must be focused on sustaining the machine of the body. Incline the left shoulder similarly over the same knee, but not to the extent that it carries the body with it; it must not lean in any direction, neither to the front nor to the side, but must remain straight and steady, naturally facing the opponent. The head is raised and centered; the neck is relaxed and natural. Now extend the sword-arm to the beginning of the thigh, but the hand a little bit apart from it, so that the hilt is not hindered in its operations by one's clothing or its edges. Holding the point of the sword towards the opponent's chest, take care that the hand does not squeeze the iron too tightly, but only as much as suffices to control it lightly, because tightening too much causes motion and delay.

The union to which Mattei here refers in the negative, as "disunited of force," is an old concept in the Italian tradition. ${ }^{5}$ It is of paramount importance in the Neapolitan school, being a central principle of their art, as we shall shortly see.

Mattei does not say so explicitly, but as a consequence of this stance the chest is squared, facing directly forward; it is not profiled in the least. This for the Spanish is the hallmark of what they will call the Italian stance, as will be seen below.

\section{The Guards}

Marcelli writes: "From this stance four guards are born, which are different postures for guarding oneself and rendering oneself defended from the different ways in which the enemy can strike. And although all motions of the sword and dagger are guards, and all can be of good effect for him who does them well, ${ }^{6}$ for all that only four were ordinarily taught by my father, because these are the most principal and most secure of all; they are the sources from which all the others derive." (1686 II I II 3)

\footnotetext{
4 Literally, "equality” (uguaglianza).

5 See, for example, Fabris (1606), "union of forces" in the text accompanying figure 5. One also sees "union of members"; see, for example, Mattei (1669) 22 and 23, and Pallavicini (1673) 23.

6 Cf. Giganti (1606) 3.
} 


\subsection{First Guard}

The first guard 7 is the guard under the weapons (guardia sotto l'armi) or the half moon (la guardia à mezza luna). (Marcelli 1686 II I III 4). 8

\section{D'Alessandro says that it is}

called guard beneath (guardia per di sotto), which, with the dagger arm completely extended, directly in line with the left shoulder, neither lowered nor raised from this line, and with the sword withdrawn, the dagger is joined with the point of the sword, slightly crossing it, the point of the dagger slightly lowered. Others want it slightly raised, but it will be better that the point of the dagger approach a straight line as it crosses the point of the sword. It is called guard underneath because, while securing primarily the face, it guards all the rest of the body from the assailant. It holds the first place on account of the security which it provides the face and because it opens only one opening (una sol porta) to the enemy, for which it is more secure than the others, which are prone to uncover more openings or entryways to the opponent. This is the least forced and most natural guard. It is clearly seen in children when they play with sticks in place of swords and daggers, which are arranged naturally more in this manner than in any other. (1723 283)

Ettenhard is familiar with this guard, saying, "the guard that they call half moon (de media luna), and which we shall call below (de abajo), because it guards the directions that come from below the dagger". (1697 42)

Mattei describes it as follows.

In the guard under the weapons you must raise the dagger arm until the fist is in a straight line with the corresponding shoulder and ensure that both the points of the weapons are united, ready to parry and not exposing any other place except below. (1669 17)

\subsection{The Second Guard}

The second guard is the guard outside the weapons (la guardia di fuora l'armi), ${ }^{9}$ which Marcelli says "was called of old by the name of iron gate ... it opens the path above the weapons, by which part the iron of the enemy can enter, and not by another." (1686 II I IV 6).

\footnotetext{
7 The order of guards follows that of the younger Marcelli. (1686 II I II 3ff.) The first guard is illustrated in D'Alessandro (1723) 759, guardia di sotto.

8 Mattei names this the second guard. (1669 16)

${ }^{9}$ Mattei names this the first guard. (1669 16) The second guard is illustrated in D'Alessandro (1723) 759 , guardia di fuora.
} 
D’Alessandro says of it,

"and guarding, or defending, the part above, it is called the outside guard, because that name teaches to catch the opposing sword to the outside, and not to parry upwards, as some do, carrying the blow to terminate in the face." (1723 283)

Mattei says of it,

"when beginning from the guard outside the weapons... one must unite the dagger over the sword in the manner of scissors, 10 but not so much that the weapons are completely united, so that they come to be totally attached, united but not restricted." (1669 16) Rada says that this guard is called closed scissors (tijera cerrada). (1695 260)

\subsection{The Third Guard}

The third guard is the guard inside the weapons (la guardia dentro l'armi). ${ }^{11}$ This is the most commonly illustrated guard in Spanish texts, and the only guard which Villardita (1670) uses and illustrates. One Spanish author, Guerra de la Vega (1681) will name the guard inside the weapons simply as the Italian guard (33). The first guard, under the weapons or half moon, is the next most commonly illustrated. The second guard, outside the weapons or iron gate, is occasionally mentioned but never illustrated so far as we have seen.

Marcelli says of this guard,

"and because from this guard is born the fianconata, it is called la guardia à fianconata by many”. (1686 II I IV 7)

D'Alessandro says that of old this guard was called scissors. ${ }^{12}$ Rada refers to it as the open scissors (tijera abierta). (1705 III 535)

Ettenhard refers to "the guard which the Italians call entall'armi", presumably rendering intra l'armi, "between the weapons," "because it guards the directions which come between the weapons." (1697 42)

Mattei describes it as follows.

... in the guard inside the weapons it is necessary to lower the fist holding the dagger to the level of the waist, 13 almost to the left flank, 14 its point raised well, not completely pointing to the sky ... the dagger is always ready to defend against those thrusts that could easily attack all the space from the face to the waist, and so that the belly and

10 “. . . as if it makes an X." (Marcelli 1686 II I IV 6)

11 The third guard is illustrated in D'Alessandro (1723) 761, guardia di dentro.

12 D'Alessandro (1723) 283.

13 Spanish and Italian fencing texts from this period use the word for belt to refer to the waist. In both languages this word is cintura.

14 Marcelli (1686 II I IV 8) makes it clear that this is to close the outside line. (In sword and dagger there are two outside lines, one to the outside of each weapon.) 
parts below should remain guarded and unharmed, the sword will be able to be joined under the dagger, with which, if unexpectedly or by the opponent's deception any strike should enter into those parts, it will very easily be defended against. (1669 17)

Marcelli illustrates a play from this guard which should be described, since, if one merely looks at the accompanying illustration (1686 II I IV 9, fig. 3)15 without reading the text, the attack resembles an ordinary lunge, not the Neapolitan sbracciatura (see below). In fact, this is a fix-footed attack, not a lunge, and the play is the fianconata, which gives its name to this guard. Marcelli describes it as follows.

... while the opponent strikes, one moves the dagger to parry it and drives the sword forward in second under the opponent's. One carries the dagger with the parry as far as the point of one's right shoulder, where it stops, and the opponent is wounded in the right flank (fianco), as the figure shows. (1686 II I IV 8)

\subsection{The Fourth Guard}

The fourth guard 16 is the guard with the sword forward (la guardia di spada avanti. (Marcelli 1686 II I III 4) Because this exposes the sword to the danger of being found, Marcelli says that in this guard the sword point is kept in constant motion in order to prevent this. (5) Its one appeal is that it is strong in the parry, since both weapons can be used together. (5-6)

D'Alessandro warns that beginners should not be introduced to this guard, who, "not having acquired all the union necessary for the game of sword and dagger" would be disunited. (284) Here is a clear indication of how important the principle of union was to these fencers. One does not see this guard mentioned by Spanish authors. ${ }^{17}$

\section{On Advancing in Stance and Lunging}

We now turn to advancing while in stance and lunging.

Villardita (1670 27) says:

"... standing in the mode indicated, one must then approach, the right foot gliding, carrying the toes of said foot raised from the ground with the aim of being more united in stance, and carry with it the left foot proportionately in one self-same tempo, and when in measure, thrust straight in one motion" (linear with a single straight motion the stoccata).

15 See also the figure on p. 33 .

16 D'Alessandro's fourth guard is the guard of half rest (guardia di mezza resta), a variant of the second guard, or guard outside the weapons (guardia per di fuora). The guard being described here is D'Alessandro's fifth guard. There is no contradiction here, since the four guards which the elder Marcelli taught were not the only guards, but the foundational guards, as noted above. The fourth guard is illustrated in D'Alessandro (1723) 763 , guardia di sp[a] da e pugnale tutta avanti.

17 Mattei omits this guard, naming only the first three. (1669 16) 
Here we see the detail of the upraised toes, but not the foot, with the aim of being more united in stance. Using linear [e], more normally used as an adjective, as a verb, Villardita emphasizes the thrust along a straight line taught by the elder Marcelli.

Villardita adds a few more details.

But be advised that, when the right foot moves, it is not displaced from the stance in guard by more than a span (palmo), and that, in its gliding, the leg must be carried and the thigh tensed (annervata) so that the knee does not bend [literally, "does not make a motion"] at the joint. ${ }^{18}$ (1670 27)

\section{On Lunging}

Marcelli tells us that he picked up his pen and put it down many times before he could bring himself to describe the lunge. (1686 II I V 10-11) He will do it, but Mattei will do it first, as follows. 19

To get it perfectly, the gentleman, in planting bimself in guard (that being the best guard, most to his liking), should unite himself with all speed, which consists in nothing other than the union of the stance, fortifying oneself over the left knee, holding the breath in the mouth (bocca) of the stomach, the middle of the kidneys reinforced, and in tensing (annervarsi) to the greatest extent the right thigh, taking care to maintain high, not the positioning of the right foot, but only the point of the toes of said right foot, so that the leg is totally stiff (duro), more ready and speedy on the way, and to avoid any obstacle on its journey. And no less should be hold firm all the parts from the waist below, the remainder of the body above mobile and relaxed, with the shoulders and arms easy and free for their quickness. Then, with the sword beld lightly in the palm of the hand, just enough, to lighten the arm, observe the circumstances indicated, and the left foot fixed in stance, to give immeasurable speed to the hand in extending the thrust to the chest of his opponent, to let fly the point of the right foot, not with a jump, but almost grazing the ground, to turn with vehemence the body together with the dagger, so that it goes back in the straight line in which it is found, and in terminating [the lunge] procure that both legs remain tensed (annervate), squeeze the sword, ease the breath, and tense (annervi) the chest in the very center, so that that impetus, so vigorous, adds greater pep to recovering into guard. Above all he should watch and mind that his thought consists solely in propelling the hand before any other motion, because, by having created an advantageous path for all the members, it must necessarily come first. 20

Also be careful that although in letting fly the straight thrust various movements of the body are necessary, one must compress them all into one instant, so that all in

18 D'Alessandro: col ginocchio destro teso — with the right knee tensed. (1723 757)

19 This lunge is illustrated in D'Alessandro (1723) 767, the sbracciatura napolitana.

20 Pallavicini will use the word annervare to describe both the left knee and the body in this lunge. (1673 11) 
themselves united and ready, they produce in one moment one act alone; otherwise, if another motion precedes, it will be a cause of delay, and as soon as this appears, defenses appear in the other's camp ... (Mattei 1669 18-21)

One sees something very much like this lunge in de Heredia, conventionally dated to about 1600, and also in Senese (1660), but with a forward-leaning torso. However, in the Neapolitan sbracciata or sbracciatura, 21 the torso and head are held erect from start to finish. ${ }^{22}$

Villardita describes the recovery as follows.

Then one must withdraw the right foot a little bit, or half stance, always holding the point of the sword extended towards the face of the opponent with the edge directed towards the opponent's sword, and at the same time return the dagger to its initial place, always ready to parry. Then withdraw the left foot to its original state together with the sword, and immediately form again the aforesaid stance in its center, which is formed with only one withdrawal of the right foot and one of the left foot. (1670 30)

Though the Neapolitan school also taught fencing with the sword alone, it is not emphasized. For example, Villardita introduces it only towards the end of his first treatise (1670 43). D’Alessandro writes:

... he who plays well with sword and dagger cannot fail to be a good player at sword alone and, already so experienced, just as the sword and dagger player gets going easily with sword alone, so the sword-alone player encounters difficulty and great effort with sword and dagger ... (1723 477)

The genius of Giovan Battista Marcelli does not seem to have consisted in the invention of new postures or new techniques. Instead, it seems to have consisted in choosing from among existing elements in the Italian fencing tradition of the seventeenth century, perfecting the included elements, and omitting the rest. From this perspective, when Pallavicini asserted that the Neapolitans were not the inventors of this or that, he might have been correct, but at the same time he failed to recognize the true innovation, which was to reduce the inherited repertoire of techniques and tactics, and practice the remainder to perfection.

\section{THE SPANISH EVIDENCE}

Spanish texts from the second half of the seventeenth century and the early years of the eighteenth complement the Italian texts of this period by independently corroborating some important information about the Neapolitan school. They also provide insight into Neapolitan training methods. Spaniards are writing on the basis of first-hand knowledge and encounters with Italian exponents, not on the basis of treatises; often

21 These are the terms D'Alessandro uses for the lunge.

22 Also, the resemblances may only be superficial, because we cannot tell from the pictured form of the lunge the details of its execution. 
they show open respect for the system of their opponents. ${ }^{23}$ Their concern is to adapt la Verdadera Destreza de las Armas (the True Skill of Arms) to meet this new challenge.24

The earliest Spanish texts from this period do not allow one unambiguously to pinpoint the Italian style being described; the later texts leave no room for doubt. It is to this series of texts to which we now turn.

\section{Pérez de Mendoza y Quijada (1672; 1675)}

The first Spanish author to refer to the Italian fencing tradition in the second half of the seventeenth century is Miguel Pérez de Mendoza y Quijada. In his 1672 treatise he describes in general terms a posture with the arm drawn back and held close to the body, which "foreign nations use, both Italian and French, and others, which execute a very violent, swift strike. They execute it with much strength and brevity in the chest. They do this quickly, because of continuous practice in delivering this strike." (69/127) In his 1675 treatise Mendoza illustrates one guard, the guard under the weapons (guardia di sotto le armi, or mez:a luna, half moon), calling it the Italian posture (postura italiana). This illustration is in the context of showing various fencing postures. Otherwise, he does not discuss the Italian tradition at all, but it is clear from the illustration that for him the quintessential Italian guard was one with sword and dagger, the torso squared towards the opponent. He uses a common and recognizable guard to show this, one that was very common in Italy, from north to south: one sees it the treatises of Bondi di Mazo (Venice, 1696), Marcelli (Rome, 1686), and Pallavicini (Palermo, 1673). On the other hand, Gorio (Milan, 1682) describes a method of thrust-oriented fencing without cutting actions, grappling, or the use of off-hand weapons. Nevertheless, we can infer that for a Spaniard of this period the use of the sword accompanied by the dagger was regarded as characteristically Italian, though from that alone one cannot infer a school of fencing.

\section{Texedo Sicilia de Teruel (1678)}

In a bilingual (Spanish and Italian) text published in 1678, Pedro Texedo Sicilia de Teruel refers to an opponent's "standing squared, which they call all'Italiana, in whichever of his guards" (67). He depicts both the guard between the weapons, which he calls la guardia fianconata, (80) the most commonly depicted guard in the Spanish texts, as well as the half moon (la guardia de media luna), the next most commonly illustrated. (80) He mentions the iron gate (63). He talks about the promptness with which most times the Italians execute the thrust (estocada), (68) "the speed with which those who adopt this posture operate", (68) and he clearly depicts the sbracciatura (72). He says that Neapolitans and Sicilians fight in the same way (73), characterized by resolve, ${ }^{25}$ both in

23 D'Alessandro reciprocates this respect. (1723 21-22)

24 For convenience, we use "Spanish" as shorthand for pertaining to la Verdadera Destreza. In this context it is not an unreasonable thing to do: while it was not the only tradition of fencing in Spain, the texts from this period reflect its point of view.

25 Pallavicini, for example, uses the phrase risolversi di resolutione. (1673 17) 
first and second intention (proposta, risposta). (74) Despite some differences, in the feints and assaults, neither one can be considered superior (74).

Given the time and place, it is tempting to believe that Texedo is describing not simply Southern Italian fighting in general but rather that of the Neapolitan school in particular, though one cannot prove this on the basis of the text alone.

\section{Guerra de la Vega (1681)}

Alvaro Guerra de la Vega (1681) not only analyzes Italian fencing on the basis of firsthand experience, as does Texedo, but he also expresses a frank appreciation of the style being encountered. He writes,

The posture that with sword and dagger they say is not subject to atajo 26 is the one which we commonly call Italian; which, well made with all the parts and circumstances of posture of dagger and body, knowledge of the distance, or the proportionate mean (medio proporcionado) for it, is the best of the tretas, ${ }^{27}$ or to say it better, the pith of the practical destreza, 28 even if its execution and perfect knowledge is difficult. (33)

... It consists, along the line of the diameter, of an interval of three feet from the left foot to the right. The right foot, whether it be for entering with the thrust (estocada) or for entering in the stance, without bending the knee, that they call being annervato (que llaman estar nerbado) ${ }^{29}$, almost without setting it on the ground ${ }^{30}$, completely ready to discharge his strike when in range, since the disposition does not enable parrying with the sword, nor placing the atajo (as has been said), since the shortest path for striking cannot be impeded (which is not to be subject to the atajo). The sword completely withdrawn, its hilt almost to the pocket of the right thigh, 31 the point aiming at the waist of the opponent, right foot forward, both heels in line, as will be seen in the illustration, from the waist below almost profiled, from the waist above squared, body and legs, the lower (being ready) the better. The opponent does not have disposition for cuts, since be does not have the range, which is more necessary for cuts. The dagger only reaches to the hand or arm, which serves little, since by thrusting the

26 A technical term in la Verdadera Destreza which denotes intercepting or impeding the path of the opponent's sword. It can refer to a specific method of doing so, as here, or to the general concept.

27 A treta is a fencing action born in the mind and put into play sword in hand. See Arias de Porres (1667) 51.

28 "Destreza" means "skill", but it was also the common Spanish term for the art of managing the sword. (Rada 1705 III 6)

29 In addition to the standard forms, one also finds nervare in Villardita. (1673 14)

30 This recalls the precise instructions in the Neapolitan texts.

31 This echoes the language of the Neapolitan texts, that the sword should not be held so close to the hip that one's clothing could hinder the free movement of the hilt. 
arm forward at the same time (which is the true parry) be is defended without being deprived of his posture. The dagger is as extended as the arm can make it, at a right angle with the corresponding collateral 32 and also at a right angle with the chest, the dagger in an obtuse angle, covering oneself with it or not giving disposition except to the side of the body. (33-34)

The guard Guerra de la Vega illustrates is the guard inside the weapons (la guardia dentro l'armi or la guardia à fianconata), the guard which most often appears in Spanish treatments of Italian fencing during the second half of the seventeenth century and early eighteenth, as has been said. Pallavicini considers this guard to provide three openings: in the middle, under the dagger, and to the outside. He also considers the position of the dagger to impede one's view, so that one cannot see the path of the opponent's sword. (1673 13) The younger Marcelli criticizes Pallavicini on this point, giving advice on how to correct the guard so that there is only one opening, and making the point that "all the postures and all the guards are good in fencing, but they must be made in such a way that each one of them should not give more than a single opening (una porta sola) to the opponent where he can strike.” (1686 II I IV 7)

Marcelli's words are corroborated by Francisco Lorenz de Rada, who wrote several important treatises on la Verdadera Destreza de las Armas. He observes, "and in whichever of these they stand, they seek not to offer their opponent more than one point where he can direct the strike. These are the most essential points that they observe when standing in guard." 33 (1695 260)

One is led to think that Guerra de la Vega is not simply describing a generic Italian guard, but one formed by a Neapolitan fencer, or one similarly trained. One can at least rule out a student of Pallavicini's school.

\section{Arrieta Arandia y Morentín (1688)}

Juan Antonio de Arrieta Arandia y Morentín, deputy maestro mayor (chief fencing instructor) for Navarre, in referring to the fencing stances (plantas) which it is possible for the human body to assume, writes that "the fourth and last is withdrawn, in which the Italians stand" (10). The first, second and third are the Spanish, French and German, respectively, with the German differing but little from the French. He also mentions a fifth, African posture. 34 He also writes

In first intention ... is formed a strike which the Italians and Spanish use much, which is to keep the sword in motion, striking over the opposing sword, subjecting and deviating it in one tempo, removing the body from the dangerous place, joining the actions of the body and sword." (50)

32 In Destreza terminology, the collateral is an imaginary vertical line between the center of the chest and the flank. There are two such lines, one left and one right.

33 Cf. Villardita (1670) 24-25.

34 The brief discussion here is reminiscent of Mendoza (1675 37a), who lists the same nations with a very brief characterization of each. 
The younger Marcelli mentions this technique when describing how to perform the guard with the sword forward (la guardia di spada avanti), (1686 II I III 5) as mentioned above; however, we cannot infer from Arrieta's description what guards the Italians he mentions are using.

Arrieta mentions the Italian stance (52) but does not describe it.

It is not possible to infer from Arrieta's text which Italians he is describing. It is included here simply for completeness.

\section{Lorenz de Rada (1695)}

Francisco Lorenz de Rada describes three Italian guards in one of two texts by him published in 169535: the guard between the weapons, the guard below the weapons (the half moon), and the guard of the outside (iron gate).

Rada will first describe the form or mode of standing in guard with sword and dagger in the planta Italiana, or Italian stance.

"The first thing which the ones who stand in guard with perfection in the Italian doctrine with sword and dagger, do is to square the body directly towards their opponent and, having placed the feet in parallel lines, turn the left one to the outside until the beel is brought close to the ankle of the right so that both feet form a right angle... Keeping the feet in this position, they bend the left knee ... and keeping the line of direction 36 over the heel of [the left] foot, which serves as an edge, they extend the right one straight forward until from the point of the left heel there is the distance that the sword has from the point to the quillons. And when this distance is established, they make the right leg and thigh straight so that there is no angle in the back of the knee. Rather, from the foot to the hip socket it is a straight line, and at the same time as they extend the foot they put the two weapons in place. They let the sword-arm fall from its source [i.e., the shoulder], naturally brought close to the right vertical, 37 remaining perceptibly curved. The point of the sword points by the shortest path to the center of the opponent's chest, if he is squared, and if profiled to the right collateral. 38

They do not insert more than the index finger inside the guard, but if the grip is of sufficient length, they do not insert any; this depends on the sword. They extend the dagger arm, and put it in front fingernails up, the pommel pointing to the horizontal line $^{39}$ of the body, and the point no higher than the plane of the eyes. (1695 258-259)

35 See References.

36 "We call line of direction in the body that which falls directly over the foot that maintains it. If it should be equally over both feet, we consider it to fall in the interval between them." (Rada 1705 II 73)

37 The imaginary line along the flank.

38 Again, the collateral is an imaginary vertical line between the center of the chest and the flank.

39 Roughly, the median plane. 
Here Rada is describing the guard between the weapons, the most commonly depicted guard in the Spanish texts.

And when they do not want to place the dagger in this position, they raise the arm more, placing it at the height of its source [the shoulder], turning the hand fingernails down, until the dagger is diagonal to the face in the guard, which they call half moon (media luna). (259-260)

This, the guard under the weapons, is the second most commonly cited Italian guard in the Spanish texts.

Also, when they want to lie in wait, they move the dagger to the right so that the point is on top of the sword, offering a point to the opponent in the left collateral. 40 They call this guard the closed scissors (tijera cerrada). 41

Rada has effectively described the three most common guards of Marcelli's system, independently corroborating the Neapolitan texts on the basis of direct observation, using the technical language of la Verdadera Destreza to do so.

\section{Tamariz (1696)}

Nicolás Tamariz, deputy maestro mayor (chief fencing instructor) for Seville, has a section on how to face an Italian which is based completely on the 1695 work of Rada cited here, which he mentions by name. Since Tamariz summarizes Rada, it is unnecessary for our purposes to give his version of what Rada has to say, when we can look at Rada directly.

\section{Ettenhard y Abarca (1697)}

Francisco Antonio de Ettenhard y Abarca describes three Italian guards. The first is the guard inside the weapons; the second is "the guard which they call half moon (de media luna), and which we shall call below (de abajo), because it guards the directions that come from below the dagger." (42) If a swordsman in any of the two guards should lower the dagger arm, making it a bit transverse, "turning the shell upwards, be will be in the fianconata, which we call the outside guard, because it defends the directions that come from the top and outside of the dagger." (42) These are Marcelli's first three guards, with the exception that Ettenhard applies the term fianconata to the guard outside the weapons (the iron gate) and not to the guard inside the weapons, for what reason we do not know. 42

\footnotetext{
40 Once again, between the center of the chest and the flank.

41 This is the guard outside the weapons, or iron gate, which Mattei described as being formed in the manner of scissors, and which Marcelli described as if it formed an X.

42 If we were to speculate, then it might reflect current, local usage, that of a particular informant, or a misunderstanding or misremembering of his own.
} 
Like Guerra de la Vega, whose work he does not know 43 , Ettenhard expresses his unreserved approbation of this new style of Italian fencing. For example, he writes that "... the Italian has all of the stated pre-eminences of the right angle with more perfection in his desplantet4 than the Spaniard in his stance", 45 and should the Spaniard wish to avoid the evident danger presented by the Italian, then "be will have to manage bis body in another manner than that which, with immovable opinion, Don Luist6 counselled ..." (58)

Ettenhard goes on to describe how Italians train, ${ }^{47}$, something which the Neapolitan texts themselves do not dwell on, though Pallavicini (1673) does describe some training methods, as we shall see below.

One detail Ettenhard mentions is that "... it is probibited with all basis in reason and true doctrine to strike enquartando la espada, which is to put it [the sword] in the form which the fourth guard teaches, when the hand is fingernails up, which is the same as to make it enter diagonally." (74)

There are two ways of thrusting for a Neapolitan fencer: with the hand in terza (third), or stoccata; with the hand in seconda (second), or imbroccata. (Mattei 1669 21) Ettenhard will tell us that when an Italian lunges over or under the dagger, his fingernails are down; if between the weapons, then the fingernails are in. Mattei tells us that the imbroccata is directed "over the opponent's arm when he is guarded outside the weapons, where, if one should perform a straight stoccata (di stoccata dritta), it would be easily defended against, but with that turn of the fist to the inside more room for striking will be found, and you will remove the force from the opponent's dagger." 48 (1669 21)

This passage might explain why there is no term for a thrust with the hand in quarta (fourth), or fingernails up, because this kind of thrust was regarded as making an angle, and the Neapolitans liked to "shoot straight": Mattei writes that, despite their different names, both the imbroccata and the stoccata are to be considered a single straight thrust. ${ }^{49}$ (1669 21) Prima (first) is similarly excluded: an imbroccata is not a thrust with the hand in prima, but with the hand in seconda. This is decidedly not old-school Italian fencing, something which Ettenhard clearly recognizes throughout his treatise. That this is Neapolitan fencing is proved by his mention of "Don Juan Angelo de Nuro, Italian author,

43 He cites previous authors seeking to show that what he is describing is something new. (32-33) 44 The desplante, an irregular positioning of the feet (planta) in fencing or dancing according to the Diccionario de la lengua española (see under desplante and desplantar), is a term which Rada will also use about the positioning of the feet of the Italians and the French, (1705 III 552) referring to the posture of the body as desplantado. (553) For a history of the usage of this term in Iberian fencing, see Rivera (2013), ad loc.

45 planta.

46 Luis Pacheco de Narváez.

$4769 \mathrm{ff}$.

48 Nuzzo glosses imbroccata as “over the fist” (sopra pugno). (1691 188)

49 “. . . siano in sustanza tutte due una sola stoccata dritta." 
in a treatise published by Iusepe Cotroni, in the year 1691..." 50 (164) This is a reference to a two-part treatise by Nuzzo (1691) on horsemanship and Neapolitan fencing. 51

\section{Rada: 1705}

In the final book of his 1705 three-book magnum opus, Nobleza de la espada, Francisco Lorenz de Rada gives the reader a systematic treatment of the Neapolitan school of fencing from a Spanish perspective. This continues and amplifies his previous treatment in 1695.

The Italian guard he illustrates is the guard inside the weapons, which he describes as follows in the context of a drill, where one opponent stands with his back to a wall wearing a plastron, and the other practices striking him, a drill which Ettenhard also describes. (1697 73 ff.)

With his back to the wall, his chest facing front, when his feet are in stance, he draws the right arm back behind the body ${ }^{2}$ and, extending the left, he puts it in front, in a slightly acute angle, 53 the hand fingernails up, and the dagger pointing up, remaining in the first guard, which they call the open scissors (tijera abierta), opening a point on the inside in the center of the chest... (1705 III 535)

The attacker will extend his legs until they are three and a half feet apart as measured from the center of the heels. Thus double-weighted, he will extend his arms fully, parallel to the ground, the point of his sword touching his opponent's chest. Rada is placing the attacker in the terminal position of the sbracciatura, to establish the proper distance for the strike. From this position, the attacker will withdraw the right foot half a foot, and at the same time assume the guard position with the weapons. The drill now commences, the attacker concentrating on striking the correct spot on his target by the shortest path, without "feinting, attacking one part in order to strike another." (535) The right foot advances half a foot in the lunge. (535) From this we can easily calculate that, according to Rada, the feet in guard are three feet apart.

The students take turns doing this, so each gets to practice the lunge and recovery, and the parry. The master is to make sure that the lunger does not feint, making as if to attack one part only to strike another, or otherwise distract the parrier, attacking by the shortest line, which is to the center of the chest.

\footnotetext{
50 Ettenhard refers to him again as "this famous Italian professor". (165)

51 Considerations of space prevent us from further exploration of Ettenhard's text. Instead, we refer the reader to Cecchinato, Luca. "Note sulla Scherma Napoletana nella trattatistica spagnola coeva: D Francisco Antonio de Ettenhard Abarca" in Lodà, Francesco (ed.). Dal trattato alla sala d'armi. Roma: Bonnano, 2013.

52 The arm is illustrated as hanging down, since it is out of play in this drill.

53 In other words, slightly lowered.
} 
Pallavicini provides a version of this drill which he says was lost in his day; it was taught to him by his first teacher. ${ }^{54}$ (1673 10-11) Ettenhard and Rada are both writing well after Pallavicini, so either this drill survived or it was revived. Pallavicini corroborates the detail that "one must not advance more than half a foot". (1673 11)

\section{Anonymous MS: 1743?}

Although it is outside the scope of the time period with which we are dealing, an anonymous manuscript in the collection of the Biblioteca Nacional de España, Libro de armas $y$ do[c]trina (1743?) 55 is of some interest as a postlude to our treatment and a prelude to further study. This text presents many similarities with la Verdadera Destreza, though there are some differences as well. For example, the author describes the medio desplante in the first lesson he gives the Spanish student (5). One chapter is entitled, Contra el tiro italiano (19). The postura italiana is illustrated (plate, 50-51). In the postura italiana, the hand is held by the hip, reminiscent of the Neapolitan instructions in sword and dagger, but an off-hand weapon is not shown. Neapolitans are specifically mentioned (20), but not in a way that echoes the concerns of earlier texts.

A further examination of this text, and of the development of Spanish and Neapolitan fencing after the time period being considered, must remain subjects of another study.

\section{SUMMARY}

This has been an introduction to the Neapolitan school of fencing as described by early authors, both Italian and Spanish, during the reign of Carlos II and the War of the Spanish Succession (1665-1714). 56 The treatment here is far from exhaustive. For example, no mention has been made of the distinctive tactics of the Neapolitan school. 57

One of the aims has been to show that, despite superficial resemblances to other schools of fencing in Italy during this period, contemporary evidence strongly suggests that the Neapolitan style when taken as a whole was considered to be something new, even if parallels can be found for important elements in other schools. Certainly, it did not arise in a historical vacuum.

The method adopted with respect to the primary sources has been phenomenological or descriptive, not speculative or explanatory. It seeks to bring to light the views of contemporary authors, putting aside any preconceptions of our own. By this means we can hope to reach surer historical conclusions, to the extent possible.

54 Marco Gerbino, a student of Matteo Galici's. Pallavicini mentions the latter as having been his teacher in his first treatise $(167014,75)$.

55 For the dating, see Valle (2012) 144.

56 Giuseppe D'Alessandro died in 1715. The work cited is the second edition, published posthumously, of a work first published in 1711. Francisco Lorenz de Rada died in 1713.

57 More information may be found Cecchinato, Luca. "Elementi di innovazione nella scuola napoletana in eta barocca: analisi comparativa dei principali autori" in La Bottega dello Storico: Le metodologie della ricerca nella scherma storica. San Marino: Il Cerchio (2011) 47-61. 
The Spanish response to this development on the Italian peninsula was driven by the need to address the lightning-fast attack perfected by members of this school. Treatment of this response is beyond the scope of this paper. 58

\section{BIBLIOGRAPHY}

Works pertaining to the Italian fencing of this period are contained in the following two sources.

Cecchinato, Luca; Rizzante, Riccardo. "Bibliografia della Scherma Italiana (1660-1803)" in Armigeri del Piave, Bollettino No 198 (Anno XXXIII), 23-26.

Cecchinato, Luca; Rizzante, Riccardo; Lodà Francesco. "Bibliografia della scherma italiana (16601815)" in Passione Stoccata, Gennaio - Febbraio 2009, 42-44.

\section{REFERENCES}

The forms given for the names of Spanish authors conform to the practice in the definitive bibliography of Iberian swordsmanship, Valle (2012).

Arias de Porres, Gómez. Resumen de la verdadera destreza en el manejo de la espada. Salamanca: 1667.

Arrieta Arandia y Morentín, Juan Antonio de. Resumen de la verdadera destreza. Pamplona: 1688.

Bondì di Mazo. La spada maestra. Venice: 1696.

Cecchinato, Luca. "Elementi di innovazione nella scuola napoletana in eta barocca: analisi comparativa dei principali autori" in La Bottega dello Storico: Le metodologie della ricerca nella scherma storica. San Marino: Il Cerchio (2011) 47-61.

Cecchinato, Luca. "Note sulla Scherma Napoletana nella trattatistica spagnola coeva: D Francisco Antonio de Ettenhard Abarca" in Lodà, Francesco (ed.). Dal trattato alla sala d'armi. Roma: Bonnano, 2013.

D'Alessandro, Giuseppe. Opera di d. Giuseppe D'Alessandro duca di Peschiolanciano. Naples: 1723. http:// amshistorica.unibo.it/48.

De Heredia, Pedro. Livre des leçons [Traité des armes]. [1600?] (Circa 1600 is the customary dating as given, for example, in Anglo, Sydney, The Martial Arts of Renaissance Europe [New Haven: Yale University Press, 2000], 359.)

Ettenhard y Abarca, Francisco Antonio de. Diestro italiano, y español. Madrid: 1697.

Fabris, Salvatore. De lo schermo overo scienza d'arme. Copenhagen: 1606.

Gelli, Jacopo. Bibliografia generale della scherma. Florence: 1890; Elibron Classics facsimile edition 2007.

Giganti, Nicoletto. Scola, Overo Teatro. Venice: 1606.

Gorio, Giovanni Pietro. Arte di adoprar la spada. Milan: 1682.

Guerra de la Vega, Álvaro. Comprehension de la destreza. Santander: 1681.

58 It has been described in Blair, Charles. Que llaman estar nerbado: The Spanish response to the Italian fencing tradition, 1665-1714. Lecture delivered at The Tenth Western Martial Arts Workshop. September 18, 2011. 
Libro de armas y do[c] trina para el resguardo de los aficionados de dicha ciencia. Con contras y explicaciones de toda la arte que se encierra en la espada. Hecho por un Aficionado. A.C.O. MS. 1743?.

bttp://bdh.bne.es/bnesearch/detalle/bdh0000136259.

Lorenz de Rada, Francisco. Crisol de la verdadera destreza, y Filosofía Matemática de las Armas. Cádiz: 1695.

Lorenz de Rada, Francisco. Nobleza de la espada. Madrid: 1705

Marcelli, Francesco Antonio. Regole della Scherma. Rome: 1686.

Mattei, Francesco Antonio. Della scherma napoletana. Foggia: 1669.

Morsicato Pallavicini, Giuseppe. La scherma illustrata. Palermo: 1670.

Morsicato Pallavicini, Giuseppe. La seconda parte della scherma illustrata. Palermo: 1673.

Nuzzo, Francesco Giovanni Angelo di. Alimento di sangue illustre, in due parti diviso, nella prima vi sono notate alcune regole dell'arte di cavalcare; nella seconda alcuni documenti della scherma Napolitana. Palermo: 1691.

Pérez de Mendoza y Quijada, Miguel. Principios d los cinco sujetos principales, de que se componse la filosofía, y matemática de las armas, práctica, y especulativa. Pamplona: 1672. Edición crítica por Manuel Valle y Jaime Girona, AGEA (Associación Galega de Esgrima Antiga) Editoria. Santiago de Compostela: 2011. Citations are given to the page in the original edition, followed by the page in the critical edition, e.g., 69/127.

Pérez de Mendoza y Quijada, Miguel. Resumen de la verdadera destreza de las armas en treinta y ocho asserciones. Madrid: 1675.

Rivera, Tim. A Glossary of Common Iberian Fencing. St. Louis: 2013. bttp:// spanishsword.org/files/common.fencing.glossary.pdf.

Senese, Alessandro. Il vero maneggio della spada. Bologna: 1660.

Tamariz, Nicolás. Cartilla, y luz en la verdadera destreza. Seville: 1696.

Texedo Sicilia de Teruel, Pedro. Escuela de principiantes. Naples: 1678.

Valle Ortiz, Manuel. Nueva bibliografía de la antigua esgrima y destreza de las armas. Santiago de Compostela: AGEA, 2012.

Villardita, Guiseppe. La scherma Siciliana. Palermo: 1670.

Villardita, Guiseppe. Trattato della scherma Siciliana. Palermo: 1673. 